\title{
I. Learning and Magic
}

I

Carl Linnæus began his study of the natural sciences during his school years at the Växjö Grammar School. By this time we find him engaged in excursions in the country; he read medicine and botany, a common combination of subjects in those days, subjects, which were eventually also to form his vocation as a scientist. During the last years at school he acquired the rudiments of medicine by reading Herman Boerhaave's Institutiones under the guidance of Johan Rothman, M.D., a County Medical Officer in Växjö. Rothman was a pupil of Boerhaave, about whom it has been said that he "must be regarded as the greatest physician of modern times". ${ }^{1}$ Later during his sojourn in Holland, Linnæus himself became a disciple of Boerhaave who remained his never-forgotten teacher and friend.

The first results of Linnæus' apprenticeship in the sciences came to the fore in his preoccupation with healing and aromatic herbs. His insights into the subject are laid down in a literary document which Linnæus started to write at the age of eighteen and continued up to his student days ( $1725^{-}$ 1727). These notes have, in our time, been published under the title Carolus N. Linnæus' Örtabok ('Book of Herbs'), edited in 1957 by Telemak Fredbärj, M.D. This little notebook is remarkable as being the first, still immature fruits of Linnæus' botanical and medical reading. It betrays its origins in the tradition from Dioscorides and Galen, and reflects the neo-Hippocratic medicine received by Linnæus in Boerhaave's school. The Paracelsic medicine, distinctive of the sixteenth and the first half of the seventeenth century, had had its day. Robert Boyle and Herman Boerhaave had already relegated spagyric iatro-chemistry to the history of learning, but its traces had not entirely vanished. Notwithstanding newer advances the old Hippocratic and Galenic tradition still retained a place in the general concepts of Linnæus' days.

1 Charles Singer (and E. A. Underwood), A Short History of Medicine, Oxford I962, p. I49. 
Plate I

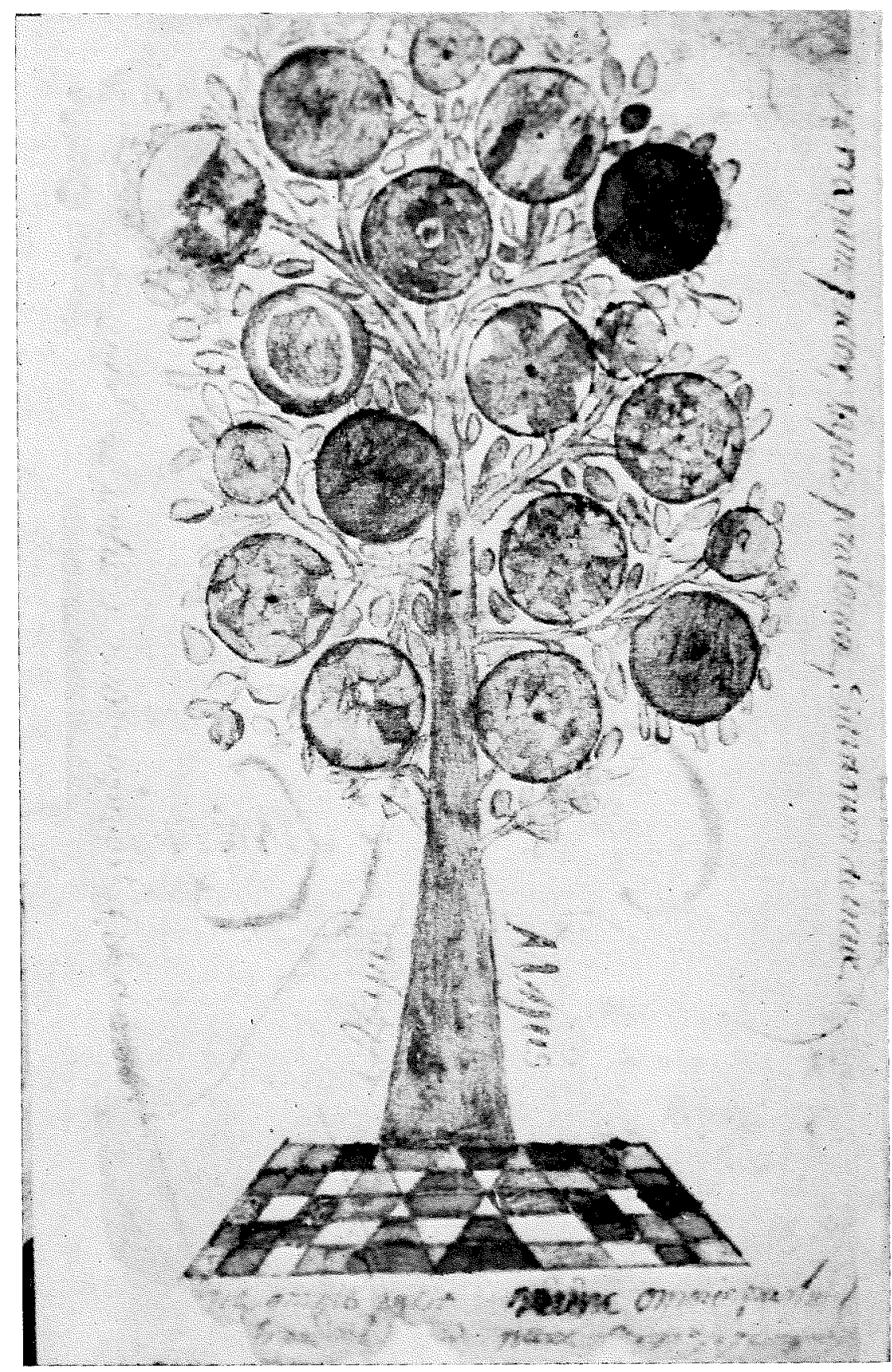

Arbor Majalis (Linnæus' Örtabok). 
Plate II

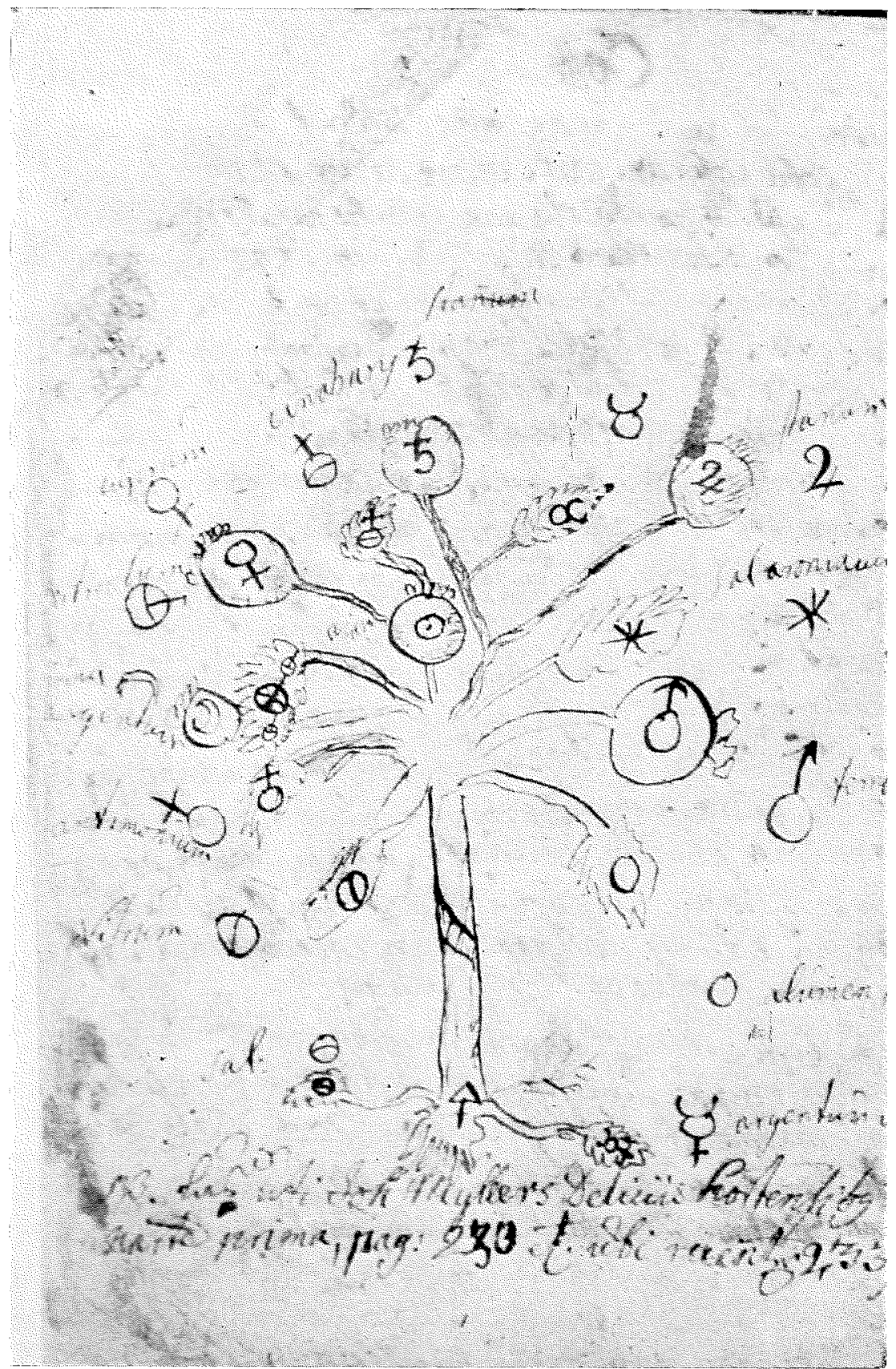

Arbor alchymiæ (Linnæus' Örtabok). 
In the next few years the young Linnæus' study of Nature turned to what he calls a more autoptical line. When in 1729 and $173^{\circ}$ the earliest seeds of his famous Sexual System for plants were laid down, their title was: Praludia sponsaliorum plantarum ('Preludes to the Wedding of Plants'). Its sub-title lays stress upon his intention to treat the physiology of plants, to show their sexes, and their modes of generation, as well as to reveal the striking analogy between plants and animals. ${ }^{1}$ Linnæus was not unaware of the importance of this discovery and inserted it into his Systema Naturæ (first edition I735). For Linnæus the sexual dichotomy in Nature becomes a primary matter of fact.

In his twenties Linnæus was very widely read in the science of nature of older times. His reading is shown in his Örtabok as well as in the library of his youth which contained hermetic occultism. In the catalogue of his library, ${ }^{2}$ begun as early as $\mathbf{1} 729$, we come across works which he grouped together under the heading hyperphysiologi; and names such as Agrippa, Lemnius and Mylius, in addition to Digby, Sendivogius and J. J. Becher appear there. Agrippa of Nettesheim's Opera omnia were among Linnæus' earliest acquisitions. Later on both Agrippa and Albertus Magnus are quoted in the Lachesis manuscripts.

As frontispieces of the Linnean 'Book of Herbs' from $1725-1727$ we find two trees, one in flower and one in leaf. The first of them may be called a maytree. On this page Linnæus writes: Majus, terrarum pictor, tapes pratorum, silvarum deliciæ, words which were highly significant for him. On the other side of the picture stands a bucolic citation from Vergil: Nunc omnis ager, nunc omnes parturit arbos. This is the Linnæus who is known to everyone as "the king of flowers". But his youthful 'Book of Herbs' has also two other drawings of trees, obviously depicted from a hermetical arbor alchymiae. ${ }^{3}$ The root, stem, leaves, and fruits have the alchemical signs of Sun, Moon,

1 Præludia Sponsaliorum Plantarum in quibus Physiologia earum explicatur, Sexus demonstratur, Modus generationis detegitur, nec non summa plantarum cum animalibus analogia concluditur. Ed. by Th. M. Fries in Skrifter af Carl von Linné, IV, Uppsala I908 (Swedish Academy of Sciences). In Philosophia botanica, I75 I, Linnæus looks at the physiology of plants as vegetationis leges and sexus mysterium, gives a list of his forerunners. See p. II; pp. 88 sq.

${ }^{2}$ Caroli Nic. fil. Linnæi Bibliotheca medica, ed. by T. Fredbärj, Ekenäs 1956.

3 Concerning Arbor Hermeticus see Kurt Seligman, The History of Magic, New York I948, pp. I24 and 152. 
Planets, and their elements. The tripartite root is marked with the symbols of the Paracelsian triad, sulphur, mercury and salt, and on the other page we read: Omnia metalla proveniunt ex $\hat{4}, \not{\psi}, \ominus$. The figures probably come from Johann Georg Müller's Delicix hortenses, Stuttgart 1684, a book that Linnæus possessed and quoted. However one interprets these immature Lesefrüchte, it can hardly be denied that the young Linnæus was conversant with alchemical and hermetic speculations. Reminiscences of the older literature recur much later in the Lachesis manuscripts where we come across names such as Croll and Van Helmont, also Paracelsus, Cardanus and Ficino.

Carl Linnæus' great adventure in the three realms of Nature was initiated with his audacious and ardnous journey to Lappland in I732. In the month of May, when, as he says, "the land was everywhere beginning to rejoice and smile", Linnæus commenced his journey, at the age of twenty-five. In Lund and Upsala he had made an extensive study of the natural sciences, specializing mainly in botany. The journey to Lappland was chiefly inspired by the botanical work of Olof Rudbeck the Younger and his expedition to Torne-Lappmark in 1695 .

Linnæus' journey extended over nearly five months and was also made to include Western and Eastern Bothnia. Aims concerned with public utility were associated with observations and experiences which in the future were to benefit his scientific work in a variety of ways. For Linnæus the study of man in his natural environment was not the least important of his aims on the journey. The Lapps lived in an undisturbed natural environment, and their healthy life and uncorrupted customs, most particularly among the Mountain Lapps, fascinated the young traveller as much as the marvels of Lappland scenery.

The Itinerary contains therefore numerous observations concerning the conditions of life and culture, the occupations and manners, dwellings, dress, food and medicine of the Lapps. A central point is the anthropological interest in the physical and mental peculiarities of the inhabitants of the country, their adaptability to the barren conditions of nature, their healthy needs and simple habits, their secure existence, their feeling of equality and hospitality, their shamanistic beliefs, medical cures and 
superstitions. Not only the native Lapps but also the Swedish and Finnish populations of the Northern regions under Swedish rule became the objects of such ethnographical studies in the field. Across the Norwegian border these studies were, by a deviation from the route, extended to the Atlantic coast.

Linnæus' tour of Lappland earned him much praise from his Swedish contemporaries. But apart from what he included in his Flora Lapponica (I737), the literary outcome of the tour remained in the collection of the Linnean Society in London together with the rest of his unedited scientific writings. More than one hundred and fifty years were to pass before Iter Lapponicum $^{1}$ was printed in $\mathbf{1} 889$, and a good two centuries until it became possible to collate the results with Dixta naturalis $I 733$ and the outcome of Linnæus' subsequent activities up to his appointment as Professor of Medicine at Upsala in I74I. During the past fifty years the ethnographical results have attracted considerable attention. But only recently has it become possible to assess the connection of Linnæus' early writings with his outlook during his early years. This makes a reappraisal of his scientific work necessary. The analysis of the Lapp material however is outside the scope of the present study. Lapp folk-medicine, of which Linnæus himself gave a short survey, has recently been discussed by Professor Ake Hultkrantz from the point of view of comparative religion. ${ }^{2}$

During his time as professor Linnæus travelled to Öland, Gotland and Småland in I741, to Västergötland and Bohuslän in 1746 , and to Skåne in I749. On the whole these Swedish travels follow the same programme, but with a growing emphasis on their practical usefulness. They are recorded in travel diaries which Linnæus himself edited and published. In the diaries, however, we only get glimpses of the writer's own person and of his private thoughts. Only when he visited his home districts in I74I, do we find a number of recollections and annotations, which, partly at least, may be

1 The standard edition by Th. M. Fries, here cited, appeared in 1913 (Swedish Academy of Sciences).

${ }^{2}$ Iter Lapponicum, Appendix XI; Alke Hultkrantz, The Healing Methods of the Lapps. Papers on Folk-Medicine I961, ed. by Carl-Herman Tillhagen, reprinted from Arv vols. I8-I9, Uppsala I964. 
traced back to his early years. ${ }^{1}$ Recollections and experiences from Linnæus' home districts in Småland make themselves felt at the back of the profusion of fresh observations in the Lappland diary, and are also frequently to be found in his Diæta naturalis. During the year following the Lappland journey Linnæus made use of his impressions for his private tuition on the natural way of living. From I733 onwards he worked on the Diata which, however, was left unfinished.

Linnæus' Dietetic belongs to a form of literature concerned with health and longevity that has its roots in Antiquity. It attempts to unite the physiological and philosophical views of the human bodily and spiritual well-being and longevity. Hippocrates, "the father of the art of medicine", was its scientific originator in one of the few works by him which can be considered genuine, the treatise on the influence of environment on human life. ${ }^{2}$ The Greek word $\delta i \alpha \iota \tau \alpha$ has a manifold implication; it denotes life, means of sustenance, means of earning a living, way of life. The Linnean Dietetic is a kind of medicine which aims at the natural way of living and is based on what he considers as the psycho-somatic nature of man. In Linnæus' notes from the $173^{\circ}$ we discover the essence of his concept of Life and Nature. Nowhere else is Linnæus' empirical method of collecting evidence in order to establish a system of nature more clearly expressed than here. We also come across Linnæus' notion of that ruling and obstructing destiny to which he gave the ancient names Lachesis and Nemesis.

The predominant feature in Linnæus' works was his interest in Man in his natural environment, and this interest included not only health and life, disease and death, but also all the material and spiritual qualities of man, food, clothing, household goods and houses, implements and occupations, amusements and customs, medicines and remedies, beliefs and superstitions. Here, as always, we meet with the Lappland traveller Linnæus, but also the wide-awake observer of country life and customs among the Swedish people.

"Medicine", he writes in the preface to Dixta naturalis, "has progressed

1 K. Rob. V. Wikman, Carl von Linnés samling av smáländska vidskepelser I747, $S L S A$ XLVII, 1964, pp. 16 sqq.

2 Max Pohlenz, Hippokrates, Berlin 1938; Fredrik Berg, Hygienens omfattning $i$ äldre tider, Lychnos 1962, pp. 9I sq. 
so far that it must not be treated as a science in the making". He himself stuck to what he discovered empirically. "The discoveries of Hippocrates and all observers are permanent and still apply today", he states. In this connection he also refers to Harvey, "who kindled a great light among the Circulation and the Egg" and "who is said to be among the immortals". All goes to show that Linnæus in the 1730 s can be described as one of the young men of the coming age of Enlightenment in Sweden. The names of Ludvig Holberg and Olof Dalin in the Dixta foreshadow the start of a new trend in the thinking of eighteenth-century Scandinavia. The names of Bacon and Locke represent the empirical way of thought of the new times. About Bacon of Verulam Linnæus in another place stated that "Bacon saw what was failing in the sciences", and Galileo he counts among "the immortals". ${ }^{2}$

The importance of Linnæus' stay abroad I $735^{-1738}$ can hardly be overestimated. The intellectual climate of the free Netherlands brought Linnæus' thoughts on Nature to maturity; his scientific empiricism was confirmed and to his outlook on life new horizons opened. After his return to Sweden he made the following note: "Wherever there is freedom of thinking and writing, studies flourish. Wherever there is free religion, the country flourishes; where the clergy (theology) holds sway, there is nothing of this, there things are in bad way" ${ }^{3}$ Very little of his youthful philosophy of Nature is to be found in the Dixta notes, and his alchemical fancies vanished completely in the Boerhaavian atmosphere. No more than Boerhaave did Linnæus become blind to the physics in medicine. He was able to pick up this element already during his school-days from Friedrich Hoffmann's Fundamenta medicinæ $\left(\mathrm{I}_{7} \mathrm{O} 3\right){ }^{4}$ The theoretical position of Boerhaave was assessed long ago by $\mathrm{Ch}$. Daremberg in his Histoire des sciences médicales (1870) as " 1 'echo d'une iatroméchanisme, melé d'hippocratisme et de chémiatrie", 5 and Linnæus never disregarded the scholarship of his great teacher. The rationalism of the period directed Linnæus into the field of systematization

1 $D N$, pp. I 8 sq. and $L N$-MSS.

$2 L N$-MSS.

${ }^{3} D N$, p. I99.

4 The book was acquired by Linnæus in Jan. 1727 according to his Bibliotheca medica.

5 Hermanni Boerhaave Prælectiones de morbis nervorum I730-1735, door B. P. M. Schulte (Analecta Boerhaaviana II), Leiden I959, p. 2. 
of Nature. Dioscorides the Second was the name of honour given to him when in $173^{6}$ he became a member of the Academia Imperialis Leopoldina Carolina Naturae Curiosorum and thus assumed the principate of Botany which in the future was to be his special distinction. ${ }^{1}$ In the vast medical school of Boerhaavians he became an organicist and not a mechanist. His great asset during these years was, however, an insight into the subject applied in his Dietetic.

With Linnæus we thus arrive at the Century of Anthropology, where many paths meet in the far-flung field of comparative science. The ideal of his Dietetic was an animally conceived existence. The habits and rules of such an existence were the pillars of his teaching on the sound and proper art of living applied to human and social life. To the great naturalist nothing natural is alien. He searched for what was necessary in events which he called the Lachesis, and he never shrunk from the physician's frank expressions of it. He often preserved his old-fashioned ways of expressing it in the terms of the Old Testament. Moreover he adorned it with the wisdom of the authorities of Roman Antiquity, principally Pliny and the Stoics. But still more often he used the language of the art of medicine of his own time.

Through his experience of the life of the Mountain Lapps Linnæus was confirmed in his opinion about the Noble Savage. But he went further back to the earlier sources of this idea, above all, to the Hugenot Missionary, Jean de Léry, in the sixteenth century, whose famous literary work Histoire d'un voyage fait en la terre du Brézil, autrement dite Amérique, was published in Latin in 1586. Among other authors we find the Netherlander van Lindschotten concerning India (1599), the Englishman Thomas Harriot about the Virginians (I 590), the Swede Campanus Holm about the Indians in New Sweden (I702), and the Frenchman Jean Baptiste Labat on West Africa ( 1728 ). But above all we come across Linnæus' own Lapps. Linnæus was, in fact, an early representative of the anthropology of the eighteenth

${ }^{1}$ In 1736 Linnæus had the epithet Dioscorides Secundus with the emblem of the Society (a World-circle and two snakes) engraved on his signet. (Th. M. Fries, Linné, I, Stockholm 1903, pp. 244 sq.) He still used the epithet on the copper-plate portrait (1748) in Philosophia botanica. For the emblem see Werner Leibbrand, Heilkunde, München I954, plate 16. 
century. By this time there was a general tendency to emphasize the importance of studying primitive habits and customs, thus anticipating the social anthropology of later times.

Diæta naturalis remained a torso in Linnæus' large output; not even its continuation in the form of lectures on dietetics, Lachesis naturalis, brought the vast subject to a literary completion. Posterity may, for good reasons, regret that the early work never became generally known amongst Linnæus' contemporaries. For despite its fragmentary character Diæta naturalis I733 contained a wealth of material which tied up with contemporary ideas; it was new, and anticipated the future. With keen feeling for the intellectual atmosphere of the time, such men as Rousseau, Voltaire and Goethe could appreciate the genius of Linnæus, although they were some distance away both in space and time.

The Diæta shows but few traces of Linnæus' youthful excursions in occult literature. The astrological and alchemical elements have been excluded, and the outlook is essentially empirical. But when Linnæus moves on the borderlands of empirical knowledge, he still shows himself dependent upon old traditional modes of thought. On the whole his anthropological attitude is postCartesian, especially as far as the psycho-somatic relationships are concerned. An important argument for abiding by the ancient sympathy doctrine was obviously for Boerhaave, perhaps also for Linnæus, the presupposed sensus communis as a psycho-somatic substratum for co-ordinating the inner and outer world of man. It is of a certain interest to see that in Linnæus' view on emotional behaviour there is a trend in the Cartesian direction. This is quite noticeable when it comes to emotions such as anxiety, anger, joy, and fear. Linnæus is an assiduous and keen observer of sexual behaviour amongst men and animals. The sensations are dealt with in detail by Linnæus, who regards them as necessary conditions of thought. He declares that neither a child nor a sleeping person can think without sensations. But all that is thought has to pass through argumenta et similitudines. If man had more senses he would understand more, Linnæus writes, but adds: "of what nature such senses would be, I cannot tell"'.

Linnæus' psychology of the senses seems to have some affinity to the

1 B. P. M. Schulte, op. cit., pp. 264 sqq. and 389 sqq. 
Lockean views and we cannot altogether exclude influences from this quarter. ${ }^{1}$ With regard to Linnæus it is, however, difficult to discern more precisely his various philosophic references behind the lapidary style of his notes. Their general aims are fortunately more transparent. He turns away from a purely mechanistic attitude. In the Clavis notes we have perhaps some faint reminiscences from Boerhaave, if not, more directly, from the postCartesian philosophers, for instance: "I am conscious through continuous thought" (mens meditando continuo conscio). ${ }^{2}$ Id quod cogitat mens dicitur, is a genuine Boerhaavian phrase of Cartesian origin. For Linnæus as for his old teacher "the conditio humana is ultimately dependent on the causality of God". ${ }^{3}$

1 Linnæus had, perhaps, during his first year as a student in Lund, already gleaned such topics from Andreas Rydelius. In this connection the name of Andreas Rüdiger should also be mentioned. See Sven Wermlund, Sensus intermus och Sensus intimus, Uppsala 1944, pp. I49 sq., 280.

2 Clavis MS under Natura et Mens.

${ }^{3}$ B. P. M. Schulte, op. cit., p. 384 . Concerning Boerhaave the commentator, p. 4ro, remarks: "Even though his concepts of the human mind are based on Descartes, his conception of the causal connection between spirit and body, amongst other things, is more advanced. His final concepts on this subject may be traced in Malebranche's Occasionalism". 
Plate III

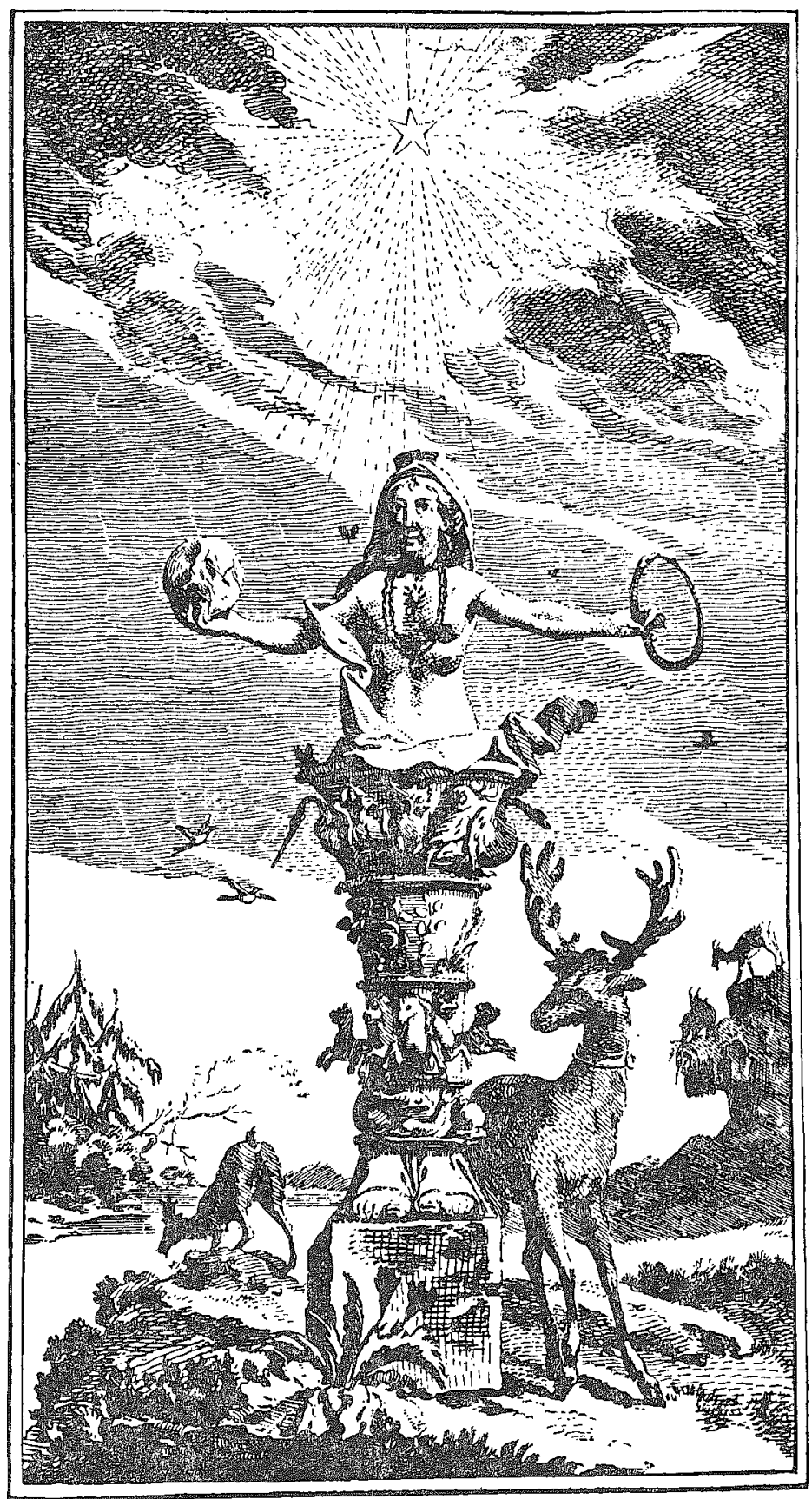

Frontispiece to Fauna Svecica 1746, engraved by Jean Eric Rhen. 3-684409 Wikman 
Linnæus' name has gone to posterity as that of the great 18 th century systematizer of Nature, above all of the vegetable kingdom. The famous Sexual System of Linnæus was a fundamental achievement of his systematizing genius. During his lifetime Linnæus made efforts to bring order into the increasing and widening mass of natural facts and finds in all the three realms of Nature. The many editions of Systema naturæ (five original editions from I 735 to $1766-67$ ) show evidence of this.

In 746 Linnæus issued Fauna Svecica, the frontispiece of which is reproduced in these essays. It is a picture of Mother Nature in the image of an Ephesian Diana in a Baroque style with, as it seems, a World-egg in her right hand and an Ouroborus in her left hand. The realms of Nature are painted on her skirt. As in the classical myth the hart accompanies Diana. ${ }^{1}$ In this connection it may be noticed that Linnæus was a naturalist of the unarmed eye. Accordingly his 'System of Nature' became a product of an eidetic holism, symbolically expressed in the copper-engraving. The original vision of Linnæus' system was the world of plants which he looked upon as in a grandiose pictorial work like those of his forerunners in the Botany of the I6th and $\mathrm{I} 7$ th centuries from Cesalpino in Italy to the younger Rudbeck in Sweden. Without such a common historical and æstetic viewpoint the system visions of Linnæus are hardly to be understood.

Basic for the theory of the Linnean system is Fundamenta botanica (I736), definitively elaborated in Philosophia botanica (principal edition I75I). Praise

1 For an explanation in details see Otto Giertz, Artemis och hinden, SLSA I946, pp. I3 sqq. Dr. Sixten Ringbom kindly drew my attention to Mother Nature depicted as an Ephesian Diana in Joannes Sambucus, Emblemata et aliquot nummi antiqui operis, second ed., Antwerpen 1566, p. 65. (According to Arthur Henkel \& Albrecht Schöne (eds.), Emblemata, Handbuch zur Sinnbildkunst des XVI. und XVII. Fahrhunderts, Stuttgart ${ }_{1967}$, col. I 534). Isis with mural crown, veil and necklace depicted in Vicenzo Cartari, Imagini delli dei degl'antichi, Venice 1647 , p. 298 (reprinted, Graz I963). 
and blame have been spent upon this work up to our own day. The principles of the Linnean taxology put down in this 'philosophy' have been passed on to the biological sciences. It cannot be our task to discuss the epistemological gap between morphologists and physiologists. Most of the renown and criticism can be thrown back into the melting-pot of I gth century biology. The vital point of Linnæus' own reasoning comes into view already in the draft of Systema naturæ, published in I735, where Linnæus declared: "The knowledge of nature consists of a true idea concerning object-matters. The objects are distinguished from one another and recognized through a methodical division and convenient denomination." The key-word in the reasoning is Method.

It cannot be denied that as a naturalist Linnæus started from direct observation and thus proceeded on empirical lines. The deciding fact was sexual fertilization as the basis for organic reproduction in general. ${ }^{1}$ Sexus initio rerum. ${ }^{2}$ The purpose of the methodological procedure was accordingly to establish organic coherences and consequently to establish the continuity in living nature. ${ }^{3}$ The method resulted in formal discerning (dispositio) and verbal denominating (denominatio) in the spirit of the systematic thinking of the age. Its scope was neither scholastic nor mathematical but founded on a 'Logic of facts', which did not lack qualitative aspects and ultimately aimed at universal perspectives. Without the binary denomination the generic name would be a "bell without a clapper", Linnæus said. As is well known the binary nomenclature still persists in the biological sciences.

The method implies an intuitive, and consequently more or less subjective, analysis developed as a comparative procedure. It is characteristic that Linnæus' observations also in medical matters often refer to his own experiences. The comparative procedure was inherent in the method. However, the mixture of empirical and rational arguments is obvious. The verification could never become exact. This is especially seen in the biased conceptualizations of general facts and reasonings. In the last words of Philosophia botanica Linnæus declares that the principle of truth must always be verified in the

1 Fructificationis partes sæpius constantissimas differentias subministrant. Sunt in fructificatione plures partes, quam in tota reliqua planta. Philosophia botanica, p. 222.

2 Op. cit., p. 86.

3 Scientia Botanices his cardinibus nititur. Op. cit., p. 97. 
Science of Nature. ${ }^{1}$ Linnæus' systems were built up as armies of species, genera, classes and ordines. Practically sean Philosophia botanica is a code for coordinating the botanical species and names in accordance with the first principle that "order is the spirit of the sciences".

The following verse is often cited as a Linnean saying:

Nomina si nescis, perit et cognitio rerum.

Actually, however, this is only a paraphrase of a passage from the 'Etymologies' by Isidore of Seville. ${ }^{2}$ The tune seems platonizing. Systema naturæ is not a pure encyclopædic outcome of the age thoughly. Accordingly the nominalistic approach of Buffon could consequently not affect Linnæus very much. As little as the system of nature, the system of disease was a product of pure abstraction.

The medical annex to the systems attracts special interest. The systematical views on the diseases were presented as lectures at the university seven times over a long sequence of years from I74I to I770. Linnæus' views were unfolded in several instalments during a long co-operation with the French physician and botanist François Boissier de la Croix de Sauvages ( $1706-1767$ ) in Montpellier. The school of Montpellier is known through its platonizing tendencies. The nosological system of Sauvages was published in 1763 . An abridgement of the closely related Linnean system entitled Genera morborum was delivered in the same year. The lecture manuscripts were edited and annotated by Professor Fredrik Berg of Upsala in 1957. The classification and terminology of the diseases was the main purpose of Linnæus, who avoided all questions concerning causes and conditions. ${ }^{3} \mathrm{~A}$ glance at the starting-points of the systems seems to indicate a basic contrast between promoting health and curing illness. The contrast is to be found already in Corpus Hippocraticum and had been further developed in the Scholastic conceptions of favouring nature by natural means and treating the evil opposite with contraries. This point of view was cardinal in the Dietetics of Linnæus.

${ }^{1}$ In scientia Naturali principia veritatis observationibus confirmari debent. Op. cit., p. 287 .

${ }^{2}$ Op. cit., p. ${ }_{5} 8$. Lector Sven Blomgren, Åbo, has kindly pointed out the passage in Etymologiae 1. I, ch. I.

${ }^{3}$ Linnés Systema Morborum, ed. by Fredrik Berg, Uppsala 1957, pp. 62 sq. 
The main concepts of the Linnean medicine, such as the insensible perspiration, the secretory and generative functions and substances and their connections with the diseases, form an empirical foundation of his Philosophy of medicine. Pre-scientific concepts, above all the principle of similia similibus, were, however, still leading motives for him. In a marginal note in the Lachesis manuscript he expressly says: "similars act on similars" and adds: "although recent authors wrongly dispute this; it is, however, certain." 1 It is rather surprising to find that Linnæus still maintained the theory "like cures like" and conversely "unlike against unlike". In Corpus Hippocraticum the sympathy-cures seem rather obsolete. ${ }^{2}$ But the sympathy-doctrine of the Stoics had obviously played a considerable part in the learned propagation of such ideas through the ages.

Linnæus' opinion about the healing powers of the herbs shows that the conceptions about the effects of contraries were still living in the therapeutics

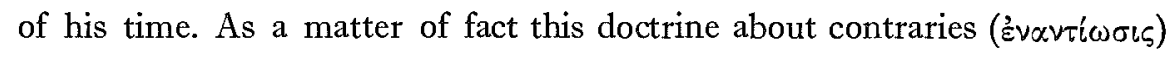
dates back to Pythagoras. Galen and the Scholastic doctors in the Middle Ages had developed it into a dialectic system with the purpose to restore or improve the deranged equilibrium by furnishing the body with contraryworking remedies. ${ }^{3}$ In the thesis De viribus plantarum (I747) it is said that the balance between the firm and floating elements of the body should be restored through the contrasting remedies. Hinc morbi contrariis morbis sæpius curantur. ${ }^{4}$ The doctrine is more dialectic than medical. Already Van Helmont in the first half of the 17 th century discredited such views ${ }^{5}$. When introduced as a part of the herbal system of Linnæus the theory of contraries acquired some resemblance to the doctrine of the Signatures, all the more since the obscure healing virtues or powers of the plants are ultimately regarded as coming from God Himself. In Clavis medicinæ duplex the theory of the

1 LN-MSS, fol. I8: Similia agunt in similia, negant recentiores, non recte, certe. In $D N$, p. I58, Linnæus refers to the axioma æeternum chymistarum of similia and contraria as rules for the digestion.

2 Joseph Schumacher, Antike Medizin, Berlin 1963, p. 209.

3 About the therapeutical doctrine of contraries in Antiquity and MA see Joseph Schumacher, op. cit. p. 47 et passim; Werner Leibbrand, Heilkunde, pp. 20, 76, rog sq.

${ }^{4}$ Op. cit., pp. 3 sqq. Cf. Otto E. A. Hjelt, op. cit., pp. ro4 sqq.

${ }^{5}$ W. Pagel, F. B. van Helmont, Osiris VIII, 1948, p. 404. 
contraries is stretched to its utmost point. At the same time Linnæus commented on the subject in a thesis where it is said that five abnormal states of the body usher in as many correspondent diseases and their contraries for which nature indicates as many remedies and their contraries. ${ }^{1}$ Linnæus' unfortunate dependence upon the traditions of ancient medicine is nowhere more clearly manifested than here.

Philosophia botanica is closely connected with Clavis medicina duplex, the proper subject of which is a Pharmacy of plants. The dynamic aspect of Clavis lurks in the Linnean conceptions about the healing powers (vires) of the plants, which he develops into an entire system of medicine. Primarily the concept in Linnæus' writings is to be found in the latter part of Diæta I733, where he says that "the virtues of herbs are from God". ${ }^{2}$ Linnæus' 'Book of Herbs' overflows with quotations from old authors on plant-medicine such as Pliny, Dioscorides, Macer, Theophrastus, Prévost, Ray, and others. ${ }^{3}$ As authorities for the views in Philosophia botanica are quoted J. Hermann, R. J. Camerarius, Friedrich Hoffmann and his own thesis de viribus plantarum I $747 .{ }^{4} \mathrm{It}$ is remarkable though that the doctrines of astrologers, alchemists and signature-teachers are rejected here as well as in Clavis. ${ }^{5}$

Whenever such occult elements were primarily eliminated, the obscure concept of vires, a target for the sarcasms of Molière, still persisted. On the basis of this principle, with the key-stones of old ideas concerning the five elements, Linnæus constructed, to put it briefly, a pentacle of dualities which he thought could be brought to mobile equilibrium. The fundamentals of this medical system were then incorporated in the last editions of his Systema naturæ, thus warranting its importance as a universal view of nature. ${ }^{6} \mathrm{Un}$ -

${ }^{1}$ Dissertatio medica de effectu et cura diæteticorum generali, Upsala I766; see Otto E. A. Hjelt, op. cit., p. 75 and note $\mathrm{I}$.

$2 D N$, p. 186.

${ }^{3}$ Carolus N. Linnæus Örtabok I725, passim.

${ }^{4}$ Philosophia botanica, p. 278.

5 Astrologi virtutem ex astris influxum in plantas, signatores vires a similitudine inter plantas partem et corporis partem lrasam divinarunt. Chemici vires vegetabilium ope analyseos ignis extricare crediderunt. (As examples he names Geoffroy Tournefort and Tawry). Op. cit., p. I6, cf. Clavis, aphorism 29. Introduction above.

'Systema naturæ, r2th ed. p. r6. Cf. Erik Nordenskiöld, En blick på Linnés allmänna naturuppfattning och dess källor, SLSA VI, I923 pp. 2I sqq. 
fortunately Linnæus did not notice that the old magic of the sympathies and signatures sneaked into his system.

The doctrine of Signatures, having obtained its shape through Agrippa, Paracelsus, Porta and others, is well illustrated by Oswald Croll's Tractatus de signaturis (1608), where is said: Ita etiam Deus cuique Plantæ indidit proditorem suum, ut genuinæ vires Herbarum latenter absconditæ per Signaturas externas, id est similitudinem Formæ atque Figuræ ex illarum aspectu cognosci, divinari ac manifestari possint; imo ut modo dictum, illæ magice nobiscum per Signaturas loquuntur. ${ }^{2}$ Although Linnæus never was an adherent of the Signature-school, smells and odours of grass or plants were somehow combined by him according to their qualities and effects. It is an experience, very often stated by him, that animals instinctively avoid eating certain plants. ${ }^{3}$ Even if already in Diæta he had declared the virtues of plants as originating from God himself, the qualities of opium or quinine were just as obscure as those of mercury and magnets. ${ }^{4}$ In such a way their effects were magically warranted. Seen thus the views of Linnæus become a faint adumbration of a rationalized magic. Much of that is a combined product of new science and old learning. The core is hidden in the obscure and floating conception of virtues and effects.

${ }^{1}$ Philosophia botanica pp. 283 sqq.; already in $D N$ pp. I72 sqq.; Otto Hjelt, op. cit. p. II3.

2 Oswald Croll deals in detail with the signature doctrine in Tractatus de Signaturis (I6o8), pp. 28 sqq.

${ }^{3} D N$ p. I 86. Linnæus apparently rejects the explanation of F. Hoffmann.

${ }^{4}$ DN, p. I73; Philosophia botanica p. 287 (refers to the treatise Pan Svecicus I 749). 
Mind and Nature belong to Linnaeus' explanations of causes and effects. The purposes of Nature are always living realities for Linnæus. The ambiguous doctrine of sympathies covers at times the theoretical need for causal explanations. Here he almost falls back into a magical manner of thinking. His magic is, however, always Natural magic, accordingly depending on reasoning; at any rate it can be ultimately reduced to such principles. When he speaks of the healing effect of plants a conspicuous tendency appears in his reasoning to see in it the signs of a Divine order. He makes a conspicuous use of similarities and contraries as medical principles, but, I think, hardly as explanations of more empirical notions. Homœopathic magic hadlost much of its former importance. More recent ideas are involved in contagiousness. It is of some importance to note here that the vicissitudes of the ideas about contagious diseases was a very intriguing question for the contemporary physicians from whom it is possible to learn about the state of scientific progress in medicine. Obviously these various views were also dependent upon the overwhelming physical problem of actio in distanti in the science of the period. ${ }^{1}$ Concerning such forms of sympathies Linnæus remarks in the Dixta that he cannot say if they occur, as some people say, but "the results of experiments would prove this; I have not been given comprehension to observe it". ${ }^{2}$ Linnæus' viewpoint is that of an observer, and he consequently admits the possibility of experience beyond the world of the five senses. In principle Linnæus does not even dismiss the possibility which, in our time, could perhaps be called telepathic. Linnæus' personal experiences might have appeared to him in such a light.

Although the sympathetic relationships in Linnæus' account are far from clear, they could permit direct observations of their effects. As magical sympathies we in general consider such presumed causes and events, the con-

1 Mary H. Hasse, Action at a Distance in Classical Physics, Isis 46: 4, I955, pp. 336 sqq.

${ }^{2} D N$, p. 175 . 
nection of which remain obscure or occult. As far as the rational explanation of the experience is lacking, from the viewpoint of science, of course such relations must be looked upon as unverified. In so far as Linnæus considers these sympathies to be natural, in any case in the sense of natural magic, the relation between cause and effect is no longer totally obscure. Mutual contacts between phenomena, affecting them partially or completely, are regarded as explanatory of the mysteries of life in a way quite different from their mere similarity. The problems of the expanding natural science of the period lay behind such considerations. Linnæus often gave his attention to them and it can only be said that he scarcely found any other answer than that offered by Aristotle's old theory of purpose being part of cause. Certainly he had a decided need to seek an explanation of the inexplicable in Nature herself. Old and new are thus combined in Linnæus' Dietetic, which includes both learned and popular beliefs.

For Linnæus magic was not just superstition. It was an old theoretical system founded on a knowledge of the connection between the phenomena of nature and expanded into a grandiose philosophy based on life and the world. This philosophy is to be found in the literature of the Renaissance and the Baroque. Although not very much more than remnants of the philosophy of magic prevailed over the common sense of eighteenth-century science, the elementary conceptions of magical thinking still existed in many quarters. The great systematizers of occult wisdom, Pliny and Agrippa, were well-known to Linnæus. And his own systematic mind could hardly remain unaffected by the thinking of the preceding period in medicine and botany. Consequently we sometimes find Linnæus' way of thinking not very far removed from a magical system.

Linnæus points out that his views on magic depend on a threefold foundation (nititur triplici fundamento) and he enumerates the various types which, in his opinion, support the theory of sympathies. ${ }^{1}$ According to his hypotheses magic is derived from the following facts:

I. excreta applicata ad alius,

2. intentio,

3. attraxio corporum.

${ }^{1} L N$-MSS, fol. $18^{\mathrm{r}}$. excretions applied for other purposes, intention, attraction of bodies. 
In addition to these there are four accidental causes:

4. electricitas magnetica,

5. affectuum actio et natura,

6. odoris affectus,

7. metus in odontalgia ab instrumento. magnetic electricity,

action and nature of affects, affects of smell,

fright of surgical instruments used to cure the toothache.

The chief arguments in his hypotheses may be interpreted as:

I. the products of bodily secretions and excretions may be used for purposes beyond their natural function;

2. human intentions and attitudes of mind may bring about distant effects;

3. animal bodies may possess an attractive magnetic power. The other points may be regarded as rather special cases and are hard to distinguish from those mentioned above.

Linnæus' 'hypotheses' are a general topic of what he calls 'magic'. Their origin is to be found in a mixture of empirical and magical viewpoints. The empirical elements are of a physiological, physical and psychic nature. The magical principle is a doctrine of sympathy, substantially reduced to contagious causation and intentional activity. Theoretically and operatively, this magic is founded upon ideas of living nature, for it never comprises stars, letters or numbers. Natural magic, in contrast with superstition, somehow constitutes for Linnæus credible, although tentative knowledge.

Linnæus' theory concerning magical thinking is not entirely his own. Much of it can be traced back to Jan Baptista van Helmont. Already half a century before Linnæus, in 1683 , similar views had been proposed in the thesis De magnetismis rerum presented before the Faculty of Philosophy in Upsala by Erik Odhelius (Odelstierna, r66r-1704), better known as a student of mining and chemistry than as a physician. In his sonorous Latin thesis the young medical student expressed medical folklore in terms of animal magnetism, vaguely applying the principle of magic as concept of causality to the supposed effects of magnetic power. His idea is that the 'magnetisms' are effluviating and active forces working not only in material connections but also 'diastatically', at a distance, and perhaps also activating living rather than dead substances. His ideas are derived from the philosophy of older 
authors, especially Agrippa, Paracelsus, Van Helmont and Becher. At the same time, however, we can discern in him a future adept of the new sciences. ${ }^{1}$ This is apparent from the names of Swedish adherents of Cartesian ideas to whom he refers, names such as the physician Peter Hoffwenius, and the mathematician Johan Bilberg, who presided at the public examination of his thesis. Apart from these two Odhelius also refers to the French physician and philosopher Jean-Chrysostome Magnien (Magnenus), who was a professor at Padua and was known as a revivalist of the atomistic theory of Democritus.

Odhelius' aim seems to have been to try to throw more light on both the old hermetic wisdom and the new teachings on the subject in order to reach consistent, although plainly ficticious explanations. Such an ambiguous tendency would appear to have been not quite unfamiliar in the era of rising Cartesian ways of thinking when Lutheran orthodoxy prevailed. In 1687 , the year in which the definite emergence of the New Science at the University of Upsala took place, Bilberg's pupils² applied more scientific views to the magnetic phenomena. Certainly, however, the force of the magnet still held the role of a "sheet anchor" for varying occultist views concerning human nature. This force had a rather strange faculty of surviving long after this epoch. Mesmer's animal magnetism is the best known in this connection.

The majority of popular practices and sayings to which Odhelius refers were most probably gathered from the household of Bishop Nicolaus Rudbeck in Västerås (Central Sweden), where Odhelius was brought up. His store of popular items is, however, neither liberal nor notable. Many of the

${ }^{1}$ Linnæus also refers to a later treatise by Odhelius about effluvia metallorum, Brussels I687. The following passage from a funeral encomium delivered by J. Upmarck reflects the contemporary apprehension of Odhelius' views: Vidit deprehenditque in humani corporis inextricabili labyrintho, ea in immensis Florae viridariis, ea in chemicis illis vaporariis, queis in succus $\mathbb{E}$ liquores metalla diffluunt, quae non Hermeti solum ac Hippocrati $\Xi^{\circ}$ Egyptiacis quibusque Mystis, sed ante id temporis orbi inaudita erant. Printed in C. Nettelbladt, Memoria virorum in Svecia eruditissimorum, semi-decas II.

2 The changed attitude concerning magnetism is seen from the theses by A. Plaan and G. Prosperius under the presidium of Professor Bilberg in 1687 (Dissertatio physica de magnete, ch. I, th. I. and De occultis qualitibus, $\$ \S_{4-8}$ ). I am most grateful to Dr. Ingrid Odelstierna for these statements. Concerning William Gilbert see Lynn Thorndike, $A$ History of Magic and Experimental Science, VI, pp. 3 I6 sq. 
examples are also derived from older literature, even from the days of Valerius Maximus. Here we shall omit the details. The differences between Linnæus and Odhelius in their treatment of method and material would seem considerable. Substantially, however, the core of thought had changed little in spite of the development of science during the intervening period. It is rather astonishing to see how Odhelius and Linnæus agree on the main points. Terms such as magnetism and imagination are merely changed to attraction and intention. ${ }^{1}$ In several places the likenesses apply even in details. A decisive instance to prove this point is that in the Diæta manuscript, whenever Linnæus mentions magnetism, he refers to the works of Odhelius. The following passage from the Diæta would appear to be taken from Odhelius:

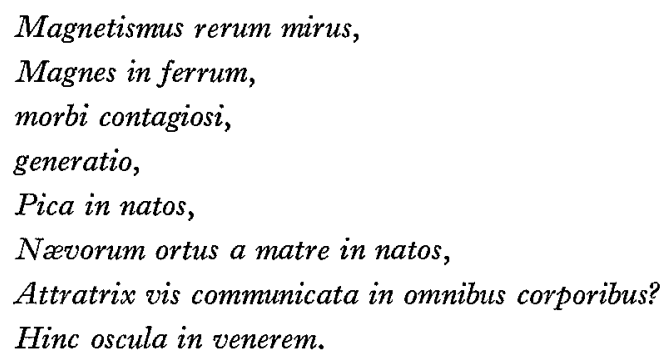

This list ${ }^{2}$, which obviously is put down at random, cannot very well be comprehended without the help of Odhelius' work. The account which concerns a vicarious sacrifice of the Massilians, and the note about the ancient custom of mixing blood are taken directly from his work. ${ }^{3}$

This subject is, however, also important in that it gives us the possibility to pin-point a relative date when the Lachesis notes on magic were originally written down. If, according to my surmise, the last sections of the Diæta manuscript were even partly committed to paper as late as around the beginning of the 1740 s, we can presume that Linnæus originally worded his magical 'hypotheses' about the same time. ${ }^{4}$

\footnotetext{
1 Probably the changed terminology reflects a difference in the general concepts of the time.

2 Details are observed in the notes below.

${ }^{3} D N$, p. I8I, also in $L N$-MSS, compared with E. Odhelius, op. cit., ch. I, th. 5 . The note Sanguis in Lachesis also refers to this author.

4 Concerning the origin of the latter part of $D N$, see my note in $S L S A$ 1967, pp. 92 sq.
} 
At this juncture it would seem worth-while to consider Linnæus' magical categories for a moment. In the first place we must note the conspicuous importance which he attaches to the contagious relations. This reflects the Linnean medicine at a very vital point. Its somewhat obscure empirical core lies in Linnæus' supposition of contagia viva. In his prelections concerning the system of diseases this theory was set out more explicitly. The materials have recently been published and commented upon by Professor Fredrik Berg, Upsala. ${ }^{1}$ In many instances the facts do not cover the theories, at any rate not to an extent which would allow any far-reaching conclusions or could be incorporated in a more general order. Conspicuously this disposition of Linnæus' grew stronger during his later years. Rather striking is the interest with which he regarded the mint as an anti-conceptional means. ${ }^{2}$ This is not only an idea ascribed to Aristotle but also a curious experience of the mintwater used by his own wife. In the speculative system of Clavis several such matters are inserted.

A very important topic for the young Linnæus was the finding of Santorio's old theory concerning the insensible perspiration of the human body. This doctrine was still current and was, in Linnæus' time, among others embraced by James Keill. Very likely Linnæus' discovery of this canon aureus saved his little sister in the Christmas season of I73I, from a feverish illness. $\mathrm{He}$ placed her in a newly slaughtered sheep's carcase. This surmise seems rather probable, since afterwards Linnæus wrote down the pathetic words that he "kisses Santorio's book". Whatever the truth may be concerning this surmise, it is certain that in many instances in his Diæta Linnæus refers to Santorio and Keill. Their names are placed by Linnæus on the title-page of Diæta. Keill's work about animal secretions (in Latin 1718 ) is cited by Linnæus in several places. It is not very strange, Keill says, that bodies conjoined with one another communicate common qualities. ${ }^{3}$

An expression of the presumed effects of the rather miraculous phenomena mentioned above is the term 'attractions' frequently used by Linnæus sometimes in connection with the term 'magnetism'. These powers are conceived as working magically in living bodies. In an additional lapidary

1 Linné's Systema morborum, Uppsala universitets årsskrift 1959: 3.

2 Hjelt, op. cit., p. Io6 (Linnæus, De Menthx usu I767); DN, p. I8 г.

${ }^{3} D N$, p. I43, cf. p. 49 (Linnæus cites Keill's Medicina statica, p. I98). 
note to the Dixta Linnæus sums up most of what could be considered as such effects: the magnetic influence on iron, contagious diseases, the mutual attraction in generation, appetites in pregnancy, ${ }^{1}$ blemishes at birth and even lovers' kisses. Most of these can be found in several places in the Diæta and Lachesis. More uncertain in this respect seems the suggestion that the power of attraction could perhaps "be communicated in all bodies" (attratrix vis communicata in omnibus corporibus?). "Everything has his own exhalations", Linnæus declares in another place. ${ }^{3}$

A large collection of examples from near and far is provided by Linnæus concerning the attractive forces of animal bodies. He refers not only to the well-known story about King David, who is said to have had a young girl in his bed in order to overcome the infirmity of old age. Lord Bacon, to be sure, also vouches for a habit which was still to be found in Linnæus' time. This was to lay a puppy on the stomach in order to remove pain. Linnæus himself refers to two conspicuously well-known cases. ${ }^{4}$ Another set of examples of attraction is represented by the tale about the old philosopher Heraclitus who is said to have cured himself of dropsy by creeping into the carcase of a slaughtered ox. ${ }^{5}$ The magical character of the foregoing examples unveils itself in the alleged consequence that the animal became infected.

It is noticeable that in this connection magnetism only plays a minor role

$1 D N$, p. 207, about the cupidities (pica) see op. cit., p. I63. Cf. E. Odhelius, op. cit., ch. II, th. 9 .

$2 D N$, pp. 207 sq. Presumably Linnæus means dead bodies. Linnæus must here be referring to E. Odhelius, op. cit., ch. II, th. I2: Neque vero metallis adeo frequens competit Magnetismus, ut eundem produnt vegetantia. A rather curious note is (DN, p. 208) that the people in Dalecarlia used to put warm loaves in the bedding in order that the miasmata would disappear. Probably this information was delivered to Linnæus in 1734 .

${ }^{3} D N$, p. 66. When, however, Linnæus maintains that even the shadow of the gallows (umbra arborum noxiarum) may be harmful $(L N$, p. 84$)$ we cannot but imagine that he pays tribute to popular superstitions about gallows during his own times. Cf. Johan J. Törner, Samling af widskeppelser, ed. by K. Rob. V. Wikman, I946, passim.

${ }^{4}$ A reference is also made to Agrippa of Nettesheim: Sic tradunt in torminibus anate viva apposita ventre transire anatemque emori. Occulta philosophia, 1. I, c. 2 I, cf. c. 37 . Similar views are held by E. Odhelius, op. cit., ch. III, th. 6, who also refers to the standard example of King David in I Regum I.

${ }^{5} L N$, pp. 72, 83-84; cf. MSS. 
in the magical thinking of Linnæus. The connection between magnetism and electricity remained essentially as obscure as before. It is uncertain what he means when he declares that "the life and the spark of life live in free air of electricity". ${ }^{1}$ Very likely such utterance of Linnæus ought to be seen in connection with his almost material conceptions of life and the soul.

However, applying mechanical terms to physiological phenomena could never be the same as to generalize mechanistic arguments from nature. When Linnæus speaks about the body as a machina pneumatico-hydraulica, in analogy with the Clepsydra of the old Greeks, he did not forbear to say that this machine was governed by life itself (moderaius a vita). ${ }^{2}$ For him a purely physical reasoning could hardly explain anything. As long as electricity remained obscure, it does not seem quite erroneous to say that Linnæus, at times anyhow, had a tendency to identify his electrum with the fifth element, xiher. For him electricity was "a recent innovation". ${ }^{3}$ It was credited with the ability of maintaining and nourishing the nervous system. ${ }^{4}$ And still more this fine and fugitive ethereal substance or force had the virtue of transmitting the vital spark from one generation to another in the chain of living creatures. ${ }^{5}$ In spite of all that can be said about these grandiose views, they express a groping effort to give some explanation of life's dynamics, and to open a door for new aspects on the underlying great problems. ${ }^{6}$

The most important part of Linnæus' magical physics is hidden in his doctrine of the sympathetic association of contagiousness involving the whole and its parts, which forms the essential substance of his views on the bodily fluids and excretions. At first glance these materials could perhaps be taken

$1 L N$, p. 82.

${ }^{2}$ Clavis medicinæ duplex, p. 5 . About the Clepsydra-idea see J. Schumacher, Antike Medizin, pp. II5, I17, 138 .

3 Electricum recens inventum, alia machina artificiosior. Clavis MS: Electricitas.

${ }^{4}$ Character: fluidum siccum, lenissimium, invisibile rarissinum, volubile, citatissimum, elasticum, non coercendum, sopitum excitandum. Ibidem.

${ }^{5}$ Electricitas in ovo, separato a matre. Ibidem.

6 Linnæus thought that the concomitance of respiration and circulation showed that not only the lungs but also the brain were receptacles for the electricity in the air. (Cerebrum habet systole et diastole syncronum pulmoni, non cordi. Pulmo agit in cerebrum.) At the same time he believed that the medullar substance biologically was the seat and transmitter of life. (The aphorisms I 8-2I above p. 21, Clavis MS, Pulmo.) See Clavis p. II; Egenhändiga anteckningar, ed. by Adam Afzelius, Stockholm I823, p. 201 ; O. E. A. Hjelt, op. cit., pp. I66 sq., 238 sq. 
from the old store of magical medicine. However, this would be to underrate the serious intention of Linnæus. In reality his arguments go deeper than that. When he puts blood on a par with other bodily fluids, his supposition is that these, as for instance the genital fluids, had their origin in the blood. In other cases the secretions and excretions are regarded as "unclean" and objects of general disgust not only in the human but also in the animal world. His personal distaste not only for nasty-smelling substances such as menorrheal fluid and genital odours but also for the abominable smells of the slaughter-houses in Stockholm and in Paris are vividly described by him. "We commonly flee from such odours", he says. ${ }^{1}$ With a realism peculiar to his style he describes the fright of lowing cattle, when sensing the smell from the slaughter-houses. In these cases Linnæus evinces a keen interest. From several utterances made by him it seems likely that he was very sensitive to the shedding or flowing of blood. ${ }^{2}$ Curiously enough the same is said about Pliny and Galen. ${ }^{3}$ His sensitiveness to odours belonging to the sexualsphere is shown in many places. In his speculative pharmacology from his later years Linnæus argues that tastes and smells come from effluvia working separately on the nervous system. Strong odours, especially from plants, are regarded as affecting the medullary part of the body. ${ }^{4}$ The occult virtues have merely been changed into obscure forces.

It is plausible to suppose that Linnæus was affected by such impressions when he generalized his views in terms of traditional magic and religion. His sources are partly his own, and partly known and less known, even obscure, authors from older times. He is especially fond of citing the Old Testament and particularly the Pentateuch as authorities for magic. "Blood is soul" it is said in the ritual text of Deuteronomy XII, 23, and Linnæus seems inclined to give the Old Jewish sacrifices an exegesis in terms of sympathetic magic. $\mathrm{He}$ refers to an old saying that Moses was imbued with Egyptian magic. ${ }^{5}$ The scapegoats are also interpreted in similar terms. ${ }^{6}$ It is not very astonishing

1 DN, p. I54.

2 The following passage is noticeable: Sanguis hunc fugimus; horreo adspectum sanguinis fluentis, uti menstruum. Menstrua ut inde abhorrent omnes; adhuc leuchorrhex. Transpiratio libidinosa puella. $L N$-MSS, p. 18 , cf. $D N$, p. I I3.

${ }^{3}$ Lynn Thorndike, op. cit., I, p. I67.

${ }_{4}$ Otto E. A. Hjelt, op. cit., pp. I05 sq.

5 Without naming the author Linnæus ( $L N$-MSS, fol. I $8^{\mathrm{r}}$ ) cites Agrippa of Nettesheim, Occulta philosophia, 1. I, c. $47 .{ }^{6}$ Leviticus XVI. 
that the saying "blood throws up the soul" is attributed to Homer, ${ }^{1}$ and that Kenelm Digby's famous sympathetic powder for arresting a hæmorrhage at a distance is vouched for among Linnæus' notes. ${ }^{2}$

Although Linnæus' ideas of sympathy are extremely vague, some of them seem to be held in common with Boerhaave in his lectures De morbis nervorum in the spring of $\mathbf{1 7 3 5}$. Boerhaave develops the theory that the sensations are transmitted to a sensorium commune where they generate emotions that bring about active and reactive effects in participation with other individuals. The original cause of this process is God Himself. ${ }^{3}$ Here Boerhaave adopts an occasionalist view, which, however, is not to be found in Linnæus. But when the latter includes emotional expressions of joy, fear, etc. among the sympathies, and presumes that birthmarks may result from such causes, he essentially adopts the same attitude as his teacher. As for the birthmarks, though, both Boerhaave and Linnæus take a questioning and sceptic view; mainly perhaps because the effects appear to resemble their causes rather than to derive from them. ${ }^{4}$ The touch of magic is manifest.

In the Linnean magic the list of bodily fluids and excretions is fairly comprehensive. It includes not only blood, menses and genital fluids, but also sweat, saliva, urine, fæces, pus and similar fluids, which are listed as substances. Most of this is to be found in the magical medicine of old times. Much of the material is reproduced in Pliny's encyclopædic work and is also systematized by Agrippa of Nettesheim in Occulta philosophia. But without saying any more it is clear that in his medical practice Linnæus was familiar with such primary physiological facts. His way of mentioning them is always that of a physician addressing his pupils.

Linnæus gives a very central place to the female periods. This is not very remarkable as this was the subject of observances and taboos from the re-

1 The cited passage: purpuream evomit animam obviously refers to Ilias $\mathrm{XV}, 360$, rendered from some obscure source.

${ }^{2} D N$, pp. 49, I 76 .

3 About the Boerhaavian concept of sympathy see B. P. M. Schulte, Hermanni Boerhaave Prælectiones de morbis nervorum I730-I735, Leiden 1959, pp. 26I-273, 389-39r.

${ }^{4} \Sigma u \mu \pi \alpha \dot{\vartheta} \varepsilon\llcorner\alpha$ hæc est, in gravidis imprimis, adeo sæpe efficax, ut omnino sæpe mirabilitatem excedat. Nec tamen ideo negare audeo rerum historiam quia quomodo fiat ignoro. Op. cit., pp. 266 and 276.

$4^{-684409 \text { Wikman }}$ 
motest times and also of cosmological speculations about the lunar influences on human life from the beginning of historical time-reckoning. Linnæus was no longer very impressed by the astrological doctrines when he was told of a possible connection between his headaches and the phases of the moon. In fact he could not believe in any such connection. ${ }^{1}$ In these matters Linnæus refers to a passage in Occulta philosophia, where Agrippa declares that in ancient times menstruation was looked upon as being most venomous, and he gives a long list of evil effects brought about by sorcerers with menstrual fluid. ${ }^{2}$ Linnæus gleaned several items from Swedish folklore. He tells us that women had confessed to him about having used menstrual fluid in order to snare men, although with very perilous effects. In two cases, women are said to have utilized their own menses as enchantments, but had been taken very ill as a result. A country-girl is said to have applied her first menses for similar purposes. The menstrual blood is said to have the double quality of procuring love and expelling evils, but the danger of such practices is that the woman's fallopian tubes become obstructed, or even fail to produce eggs. A remedy for this is to take another woman's menstrual fluid in order to resuscitate one's own. ${ }^{3}$ Already in Diæta Linnæus observes the particular qualities attributed to the first menstruation, an idea which is wellknown in contemporary and later folklore in Sweden. ${ }^{4}$

In accordance with embryological notions still held in his time, Linnæus supposed that the genital fluids of the woman as well as the man were active constituents at the conception. Genitura was the term not only for sperms but also for the genital secretions of the woman. The supposed connection with

1 MS in the Linnean Society of London (D. 807 , c. I), kindly communicated by Professor Fredrik Berg, Uppsala. In Varia, DN, p. 208, Linnæus puts down some notes, taken from some unknown source, concerning alleged influences of the moon on the brain and the oysters.

${ }^{2} L N$-MSS; Agrippa, op. cit., 1. I, c. 42. The subject is treated by E. Odhelius, op. cit., ch. V, th. 5, where inter alia is said that the blood retains its connections with the human body but also has effects in other circumstances: Declarant id abunde menstruatæ, quarum aspectu non solum citissime defœdantur specula, sed $\Xi^{\circ}$ totam cerevisiæ fermentationen adventu menstruatæ vi quasi destructam ocularis comprobavit experientia.

${ }^{3} L N$-MSS, fol. I 8 . The sperma as love-charm, ibidem. The notices are conspicuously of literary origin.

${ }^{4} D N$, p. 20I, and LN-MSS, cf. L. F. Rääf, Svenska skrock och signerier, ed. by K. Rob. V. Wikman, Stockholm I957, No. I883. 
the blood is very often emphasized in terms such as flos sangvinis or quinta essentia (of the blood). ${ }^{1}$ Also sweat and spit are regarded as puræ serum sangvinis, "strained out of the blood". 2

Lovers' kisses are likewise listed among these magical substances. ${ }^{3}$ The table of secretions contains several other substances of the ancient magical pharmacy, such as afterbirth, pus and stercora in popular use. ${ }^{4}$ A note from Linnæus' Lappland journey is significant in this connection: The Lapp spells a bear charm on his neighbour's reindeer in this way: whilst walking in the forest he collects some warm bear dung, which he then places in his armpit ( $s u b$ axillis). Next he takes some warm dung from his neighbour's reindeer and in this way the bear charm is cast upon the reindeer. The only way to remove the spell is to throw the charm into (running) water. This practice of the Lapplanders became, for Linnæus, a type of sympathetic magic, and it is rendered as such both in Dixta and in Lachesis. ${ }^{5}$ The magic art is rather complicated. It can be sub-divided into: the view on the virtue of the substance, the taking care of it, the mixing procedure and the intentions connected therewith. The occult virtues attributed to these products of the bodily functions are naturally central facts. However, the collecting and mixing together of the magical elements and lastly their application to evil purposes are just as important parts of the operation and must be held together as one whole.

We learn from Linnæus just how complicated and entangled with magical elements medical traditions became in the course of their long history. In this context he mentions congenital defects of children, such as birthmarks, hare-lips and fire-marks, which were acquired by the unborn baby during the mother's pregnancy. ${ }^{6}$ Linnæus only touches on the theme but, in his

${ }^{1} D N$, p. I Io.

$2 D N$, pp. 57 and 99 sq.

3 LN-MSS, fol. I8: Solus odor virosus excitat membrum ac genitalia. Oscitando imo oscitat alter. Solus tactus utriusque genituræ effecit hominem summum magum.

4 Ibidem.

${ }^{5} L N-M S S ; D N$, p. ${ }^{7} 76$ (where bron is to be read biörn, 'bear'). Cf. the author, Carolus Linnæus $i$ Vasa och Österbotten, Budkavlen XXXIX, I960, p. I03. A somewhat simpler form was practised by Swedish peasants, and Linnæus refers to this: Ferro candente urunt stercus inimici ut inde exulceretur podex. LN-MSS ibidem. Cf. at large E. Odhelius, op. cit., ch. IV, th. 3, where mother's milk and urine are treated in this connection.

${ }^{6}$ See above the sympathetic theory of Herman Boerhaave. 
Dixta, in accordance with advice in Hippocratic medicine, would appear to warn against incontinence before childbirth. ${ }^{1}$ From his own experience comes a story from Lappland, where he tells us about a pregnant woman who had looked upon her dying mother with the result that her child was born with an eye-defect. According to his requirements Linnæus brings to the fore a couple of parallel stories from the animal world and also narrates the story of how Jacob stripped the rods in Genesis XXX, 37-39. Linnæus, however, reacts vehemently against the opinion that original sin causes complications during delivery. The touch of magic appears here as clearly as it does in the short note of Linnæus that a strawberry-formed birthmark might originate from throwing a berry at the child's mother. When the berries ripened, it is said that the moles turned red. ${ }^{2}$

The magic was not so much concerned with the friendships and enmities of things (amicitia and $l i s, \varphi i \lambda i \alpha$ and veíros, in ancient conceptions), as with bringing them in contact with each other in order to pursue the intentions of the practitioner. This aspect of the practice is well illustrated above by the account of the bear-charm in Lappland. According to Linnæus' 'hypotheses' intentions (intentiones) and attitudes (affectum actio e natura) are considered as subjective causes of magical actions. A leading motive is that "faith moves mountains", by which is meant that vows, oaths, curses and imprecatory attitudes can trigger off magically acting powers in accordance with sympathetic principles. Unfortunately the words are used in such a broad sense that they can scarcely clarify much of Linnæus' hypothetical reasoning. The main argument seems to be in harmony with the principle of destiny, which, in this connection, is illustrated by examples of the self-cursing effects of broken vows in love affairs. "Perhaps one's own conscience contributes to such a condition", Linnæus says, completely in the manner of Nemesis Divina. However, the magical basis of his reasoning becomes more clear when he refers to behaviours such as anger, appetite or

$1 D N$, pp. II 4 sq.; cf. $L N$, p. I5०.

2 Such ideas were current in Småland but also-in England. LN-MSS, fol. I8: nævi baccarum efflorescunt eo tempore, quo rubescunt baccæ. For the interpretation above I am indebted to T. Fredbärj, M.D., Stockholm, who kindly informed me of a lecture-note made by Stephen Insulin in I753, in the Library of the Royal Swedish Academy of Sciences, cited by Felix Bryk, Linné as Sexualist, Stockholm 195 I, p. 45; see moreover F. J. E. Eneström, Finnvedsbornas seder och lif, I9I I, p. 74. 
hunger as occult causes for what he calls intentions. ${ }^{1}$ However, his thoughts can scarcely be expressed in terms of modern psychology. Moreover they belong to the history of magic.

$1 L N$-MSS; cf. below ch. III-IV. In this connection it is remarkable to note the slight behaviouristic observation taken from the "experiments" in the Royal British Society: Caudisona videns Sciarum in arbore, aperit os, diu timet animal, tandem os incurrit. Sic et mures. It seems likely that Linnæus seeks an explanation of these conditional reflexes in the wonderful order of Nature. It is not surprising that in another place Linnæus calls his own subjective uneasiness at the birth of his first child and the death of his mother as telepathic "intentions". 
In a little treatise called Metamorphosis humana, $\mathbf{1 7 6 7}$, Linnæus develops an old theory about the seven-year periods of human life. The reasoning was familiar to Linnæus already in his Dixta of 1733 . Here he reckons with at least six periods of seven years in accordance with the following list, which characterizes the changes of youth, manhood and old age:

Laxus, fortis, rigidus,

humidus, plenus, siccus.

In the context Linnæus promises a dietetical exegesis of the last chapter of Ecclesiastes: "Remember now thy Creator in the days of thy youth." $1 \mathrm{He}$ returns to the same topic later in his prelections. In the college-notes he still reckons with six such periods of life; manhood is, however, doubled to fourteen years before the annus climactericus fatalis ensues in the 63rd year of life. ${ }^{2}$ In the text of Lachesis the critici anni are indicated as ten periods of seven years with 70 as the limit. ${ }^{3}$ In the treatise of 1767 the perspective of the years is stretched out to 80 . The subjective character of the reasoning is, as Professor Sten Lindroth remarks, obvious enough. 4 This becomes even more significant when we find the ponderings of Linnæus about the flight of years resulting in the thought that the summit of life occurs at the 48 th year. This is a marvellously exact date (about the beginning of the $1750 \mathrm{o}$ ) for the end of the scientifically most productive age of Linnæus. We can scarcely be mistaken that Linnæus is here reflecting on himself. In Vita II he considers 1748 as the fatal year. ${ }^{5}$ Most of his remaining years were filled with recurrencies, reminiscences or sudden conceits. Nevertheless Linnæus was a man of ready wit, as Lindroth aptly observes.

It would be tempting to guess at a magical explanation of the number 7 in

$1 D N$, pp. 40, 42.

${ }^{2} L N$, the college-notes pp. 5 sqq.

${ }^{3} L N$, pp. 1 $3-16$.

4 Sten Lindroth, Linné - legend och verklighet, Lychnos 1965-1966, p. I04.

Vita II, p. 20. 
Linnæus' meditations. In fact, Agrippa of Nettesheim has a great bulk of examples in his 'Scale of septenaries'. Inter alia he says: Cum vero ad decadas septenas pervenitur, ubi septenarius per numerum completum conducitur, tunc metam communem vivendi habet, dicente Propheta: Dies annorum nostrorum in ipsis septuaginta annis. Summus etiam humani corporis crescendi modus, est septem pedum. ${ }^{1}$ The text of Agrippa tells us almost all we need to know. Also Ficino says that dangers threaten every seventh year of life. ${ }^{2}$ The periodizing of the human lifetime in septenaries is biblically founded on Psalm 9o, verse 10 in the Psalms. Philo deals in particular with the theme which shines forth in Cicero's 'Scipio's Dream,' where fifty-six $(7 \times 8)$ signifies Scipio's fatal year. ${ }^{3}$ Ultimately the idea is derived from archaic astrological views on the seven planets. ${ }^{4}$ Besides Linnæus calculates with twelve as a multiple for months and days. ${ }^{5}$ It could be suspected that such numerological and astrological notions were directly taken from Trithemius' and Agrippa's scales. ${ }^{6}$ The latter speaks expressly about the numbers seven and twelve: Habet septenarius magnam cum duodecimo conformitatem. ${ }^{7}$ But nowhere in Linnæus' production do we find such astrological notions.

It is another matter that instead Linnæus introduces Microcosm and Macrocosm in accordance with the formula: "What is inferior, is also superior."' The train of thought is conspicuously platonizing in the Renaissance sense. On the other hand we may suppose that behind this guess-work there is a vague view about a clock let into the organism and determining human nature. Van Helmont's ingenious idea of Biological time, however, seems to

1 Op. cit., 1. II, c. Io, pp. Ir4 sq.

${ }^{2}$ De vita studiorum, ch. I3, I4, 20, cit. by Thorndike, op. cit., IV, p. 564 .

3 Thorndike, op. cit., I, pp. 355 sq. (De mundi opificio c. 30-43); 273 (Somnium Scipionis c. 2); W.-E. Peuckert, Astrologie, I960, pp. 266 sq. (Ptolemy, Tetrabiblion 1. I, c. 2).

4 A survey of Linnæus' aspect is inserted in the cited Dissertatio medica sistens metamorphosin humanam, Upsala I767, p. I9. About the Scala septenarii see Agrippa, op. cit., l. II, c. Io, pp. II4 sqq.

5 Agrippa, op. cit., 1. II, c. Io, p. I 19.

${ }^{6} \mathrm{~J}$. Trithemius in the edition of the Occulta philosophia by Karl A. Nowotny, Graz 1967, Appendix V, pp. 715 sqq.; cf. p. 439.

7 Original edition of Occulta philosophia, loc. cit. and pp. I30 sq: Magna insuper in divinis mysteriis duodenariis vis est.

${ }^{8}$ C. von Linné, op. cit., p. 3. Cf. Calendarium Floræ, Upsala I 756, p. I. 
have passed unobserved by Linnæus. ${ }^{1}$ Walter Pagel aptly comments on the striking contrast concerning the time-conception between the Platonism of Plotinus and Proclus and the Aristotelianism on the other hand which goes back to the Middle Ages and continued into Modern Times: "In the Peripatetic philosophy time", he points out, "had assumed the character of a universal framework, completely unrelated to the qualities of objects or the differences between them." 2 On the contrary, time, according to Plotinus, "was an offspring of eternity, occupying a position, independent of motion and number". A faint hint of neo-Platonism in Linnæus cannot be overlooked in this context.

Linnæus' treatment of magic may seem rather bewildering. Behind his natural magic is, however, dimly seen concepts of connections of cause and effect, no longer attributed to devils or spirits but to "intelligences" or "powers", whatever they are called. Linnæus also has an apparent respect for magic as a source of knowledge. According to his 'hypotheses' the magical connection could be made active through human sentiments or intentions.

Linnæus' scientific world was still one of discovery and adventure such as it had developed during an epoch when arguments were governed by intentions and contents by form. The dimensions of time and space had no limit. The enormous widening of the world of experience led above all to the posing of problems on the way knowledge had to travel before it could gain order and create systems. Linnæus took over this task and his morphological systems became a dynamic core which later could form a basis for evolutionism. In his plant-medicinal system Linnæus, however, also included other concepts and elements of thought from pre-scientific traditions and presented 'hypotheses' concerning sympathetic connections in nature. Although empirically confined to a form which may be labelled as rather magical Linnæus himself was never a magical thinker. The pre-scientific elements in the philosophy of Linnæus will be further illustrated in a chapter about what may be called his hidden philosophy.

1 The theory of a biological time was proposed by J. B. van Helmont, De tempore I648, who deprecated not only the analogies between macrocosm and microcosm but also the sympathy-doctrines. W. Pagel, $\mathcal{F}$. B. van Helmont, Osiris VIII, 1948, pp. 346 sqq., 355 and 372 sqq.

2 Concerning the Paracelsian time-conception Walter Pagel, Paracelsus, Basel and New York 1958, pp. 72 sqq. The author is referring to Joh. F. Callaghan, Four Views of Time in Ancient Philosophy, Cambridge, Mass., 1948. See also the discussion of the problem by Helene Weiss, Osiris VIII, x948, pp. 418 sqq. 